\title{
PENGARUH TEKANAN REAKTOR PADA PENGHIDRORENGKAHAN TAR BATUBARA
}

\author{
EFFECT OF REACTOR PRESSURE ON COAL TAR HYDROCRACKING \\ Novie Ardhyarini, Daliya Indra Setiawan dan Syntha Nardey

\begin{abstract}
Pusat Penelitian dan Pengembangan Teknologi Minyak dan Gas Bumi "LEMIGAS"
Jl. Ciledug Raya Kav 109, Cipulir, Kebayoran Lama, Jakarta Selatan 12230, Indonesia

Email: novie_ardhyarini@yahoo.com
\end{abstract}

Diterima: 19 Agustus 2013, Direvisi: 8 Agustus 2013, Disetujui: 13 September 2013

\begin{abstract}
ABSTRAK
Gasifikasi batubara menghasilkan tar batubara sebagai produk samping. Tar batubara adalah campuran senyawa yang sangat kompleks terdiri dari beberapa senyawa dengan gugus fungsi berbeda dan didominasi senyawa poliaromatik. Kadar senyawa ini yang menyebabkan tar batubara sebagai bahan berbahaya dan beracun. Sifat fisik dan kimianya hampir mirip dengan minyak bumi tetapi tar batubara memiliki kadar poliaromatik dan pengotor yang cukup tinggi. Hal ini akan menjadi masalah dalam pemanfaatannya sebagai bahan bakar minyak. Sehingga tar batubara perlu ditingkatkan mutunya. Tulisan ini membahas peningkatkan mutu tar batubara dengan penghidrorengkahan menggunakan reaktor autoclave dan katalis nikel-molibdenum berpenyangga alumina silika. Pengaruh tekanan reaktor diamati. Produk penghidrorengkahan dengan kondisi operasi $450^{\circ} \mathrm{C}$ dan 120 bar memberikan hasil yang terbaik dimana terjadi penurunan SG (Specifice gravity) $60 / 60^{\circ} \mathrm{F} 19 \%$ dan peningkatan rasio mol $\mathrm{H} / \mathrm{C} 26 \%$. Kadar pengotor sulfur dan nitrogen mengalami penurunan $88,5 \%$ dan $72 \%$. Produk penghidrorengkahan didistilasi menggunakan simulasi distilasi dengan kromatografi gas.Berdasarkan simulasi disitilasi, produk dapat difraksinasi menjadi fraksi ringan $2,2 \% \mathrm{vol}$, nafta $33,8 \%$ vol dan distilat tengah $48 \%$ vol. Hasil ini menunjukkan bahwa tar batubara berpotensi untuk diolah menjadi
\end{abstract}

bahan bakar minyak. Selain itu, pemanfaatan tar batubara juga dapat menjadi solusi pengolahan limbah.

Kata kunci : Tar batubara, limbah, penghidrorengkahan, reaktor autoclave, bahan bakar minyak

\section{ABSTRACT}

Coal gasificationproduce tar as a side-product. Coal tar is a complex mixture, and consists of various functional groups mainly polyaromatic compounds. Due to its chemical composition, coal tar is categorized as hazardous material. The physical and chemical properties of coal tar is similar to crude oil, but it has higher polyaromatics and impurities. Those problems are the main challenges of processing coal tar into fuel. Therefore, an upgrading process is required. This paper discussed upgrading coal tar into fuel by hydrocracking in an autoclave reactor using catalyst of nickel-molybdenum with alumina-silica support. Effect of reactor pressure was observed. Hydrocracking product at $450^{\circ} \mathrm{C}$ and 120 bar showed the best result where the $\mathrm{H} / \mathrm{C}$ molar ratio increased $26 \%$ and the specific gravity decreased 19\%. The impurities of sulphur and nitrogen decreased 88,5\% and 72\% respectively. Hydrocracking productwas distilled using a simulated distillation by gas chromatography. Based on simulated distillation analysis, the product could be fractionated into $2,2 \% \mathrm{vol}$ of light end, 
$33.8 \% \mathrm{vol}$ of naphtha, and $48 \% \mathrm{vol}$ of middle distillate. These results showed that coal tar is potential to be processed into fuel. Furthermore, the utilization of coal tar can be a solution of waste treatment as well.

Keywords :Coal tar, waste, hydrocracking, autoclave reactor, fuel

\section{PENDAHULUAN}

Pasokan gas yang semakin sulit membuat kalangan industri mencari alternatif lain untuk memenuhi kebutuhan gasnya, salah satu cara yang digunakan adalah dengan mengolah batu bara melalui gasifikasi. Gasifikasi batubara mengkonversi batubara menjadi gas sintetik $\left(\mathrm{CO}+\mathrm{H}_{2}\right)^{(1)}$ sebagai produk utama dan menghasilkan poduk samping yaitu tar batubara dari kondensasi volatile matter batubara. Kandungan volatile matter ini tergantung dari kualitas batubara yang digunakan, semakin tinggi kadar volatile matter batubara semakin banyaktar batubarayang dihasilkan sebagai produk samping. Kualitas batubara Indonesia pada umumnya didominasi oleh batubara peringkat rendah yaitu sekitar $70 \%$ dari total sumber daya ${ }^{(2)}$. Batubara jenis ini memiliki kadar air tinggi, nilai kalori rendah dan kadar volatile matteryang tinggi, sehingga kemungkinan tar batubara yang dapat dihasilkan adalah sekitar 2,5$4,0 \%$ berat dari umpan batubara yang digunakan $^{(3)}$.

Tar batubara adalah campuran senyawa yang sangat kompleks terdiri dari senyawa alifatik, aromatik, alisiklik dan heterosiklik $^{(4)}$. Senyawa aromatik didominasi satu sampai delapan cincin (poliaromatik) $)^{(5)}$. Kadar dari senyawa tersebut yang menyebabkan tar batubara termasuk bahan berbahaya dan beracun (B3) yang tidak dapat dimusnahkan tanpa perlakuaan awal (pre-treatment) dan membutuhkan teknologi yang mahal untuk prosesnya, sehingga tar batubara lebih banyak ditimbun dan tidak digunakan.
Pemanfaatan tar batubara adalah sebuah kesempatan untuk memecahkan masalah limbah di industri.

Sifat fisika dan kimiatar batubara yang hampir mirip dengan minyak bumi membuat tar batubara memiliki potensi untuk dimanfaatkan sebagai bahan bakar minyak. Kadar poliaromatik dan pengotor yang cukup tinggi dalam tar batubara akan menimbulkan masalah dalam pemanfaatannya sebagai bahan bakar minyak, karena itutar batubara perlu ditingkatkan mutunya dengan penghidromurnian. Penghidromurnian adalah proses peningkatan mutu fraksi minyak dan/atau kestabilan bahan baku dengan memakai hidrogen dankatalis ${ }^{(6)}$.

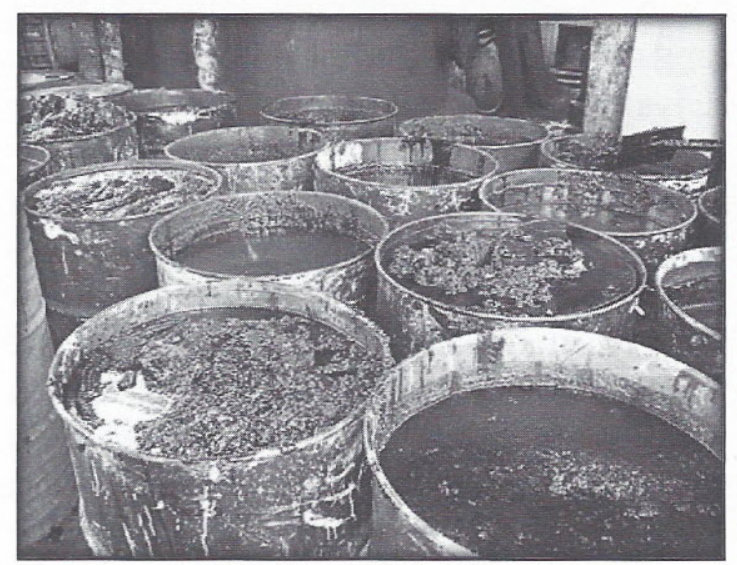

Gambar 1. Timbunan Tar Batubara di Industri

Penghidromurnian tar batubara dilakukan sepertipenghidromurnian pada minyak berat umumnya, dimana pada konversi minyak berat umumnya melibatkan dua metode yakni ${ }^{(7)}$ :

(i) Pemisahan karbon (carbon rejection) dengan mekanisme termal dimana terbentuk formasi coke tinggi sehingga didapat senyawa dengan rasio $\mathrm{mol} \mathrm{H} / \mathrm{C}$ rendah.

(ii) Penambahan hidrogen dengan mekanisme penghidrorengkahan dimana hasil coke berkurang untuk memperbanyak produk cair. 


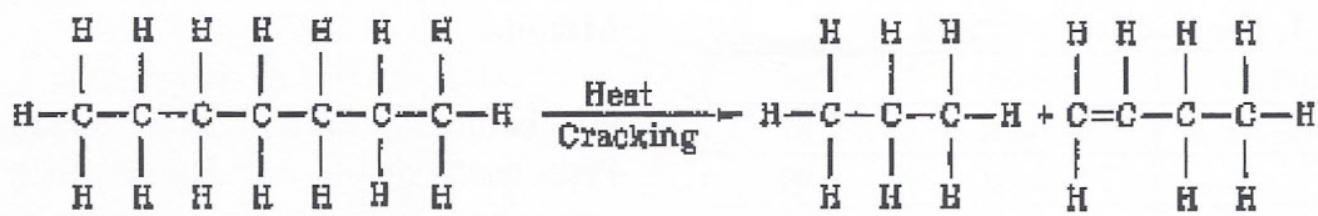<smiles>CCCCCCCCCCC(C)C</smiles>

Gambar 2. Mekanisme Penghidrorengkahan ${ }^{(8)}$

Penelitian ini menggunakan metode kedua yakni penghidrorengkahan sebagai upaya peningkatakan mutu tar batubara. Penghidrorengkahan dipergunakan dalam peningkatan mutu tar batubara karena struktur kimia dari tar batubara yang didominasi poliaromatik membutuhkan proses yang lebih keras untuk memecahnya sehingga didapatkan produk cair yang lebih besar dan pengurangan kadar pengotor.

Mekanisme penghidrorengkahan adalah proses katalitik perengkahan dengan hidrogenasi seperti terlihat pada Gambar 2. Katalitik perengkahanakan memecah ikatan tunggal karbon-karbon (C-C) dan hidrogenasi adalah penambahan hidrogen pada ikatan ganda karbon-karbon $(\mathrm{C}=\mathrm{C})^{(8)}$. Hidrogenasi juga dapat mengurangi pengotor yang berada di umpan seperti sulfur, nitrogen, oksigen dll.

Penelitian ini bertujuan untuk meningkatkan mutu tar batubara dengan penghidrorengkahan menggunakan reaktor autoclave.

Keberhasilan penghidrorengkahan ditandai dengan berapa banyak terjadi konversi dari umpan tar batubara menjadi produk yang lebih ringan. Beberapa parameter operasi yang menjadi penentu keberhasilan proses ini yaitu temperatur dan tekanan reaktor, space velocity, konsumsi hidrogen, kadar nitrogen umpan dan kadar hidrogen sulfidadari gas $^{(8)}$. Penggunaan reaktor autoclave hanya dapat mengamati perubahan temperatur dan tekanan reaktor. Pada penelitian sebelumnya telah dilakukan penghidrorengkahan pada fraksi distilat tengah dengan variasi temperatur dan tekanan reaktor. Hasil penelitian menunjukkan pengaruh variasi tekanan pada reaktor menghasilkan penurunan $\mathrm{SG}$ $60 / 60^{\circ} \mathrm{F}$ dan kadar pengotor yang lebih signifikan dibandingkan variasi temperatur, sehingga pada penelitian ini ditujukanhanya untukmengamati pengaruh tekanan reaktor pada produk penghidrorengkahan tar batubara.

\section{BAHAN DAN METODA}

\section{Bahan}

Tar batubara diperoleh dari gasifikasibatubara milik perusahaan swasta di areal kawasan industri Sumatera Utara. Uji karakterisasi sifat fisika dan kimia tar batubara menggunakan metode yang sama dengan yang dipergunakan untuk mengkarakterisasi minyak bumi sehingga hasilnya dapat dibandingkan.

Katalis yang digunakan dalam penelitian ini menggunakan katalis komersil penghidrorengkahan yaitu nikel molibdenum dengan penyangga alumina silika. Kadar logam-logam yang terkandung dalam katalis di analisa menggunakan AAS (Atomic Absorption Spectroscopy). Pengukuran luas permukaan, volume pori dan diameter pori dianalisa menggunakan metode BET (Brunauer-Emmett-Teller method) dengan peralatan adsorpsi (Quantachrome Nova 1200e) menggunakan gas $\mathrm{N}_{2}$. Hasil karakterisasi sifat fisika dan kimia katalis diperlihatkan pada Tabel 1 dan Gambar 3. 
Tabel 1. Karakterisasi Katalis

\begin{tabular}{|l|c|c|}
\hline \multicolumn{1}{|c|}{ Parameter } & Satuan & Hasil \\
\hline Konsentrasi : - Ni & \%-berat & 2,87 \\
\hline \multicolumn{1}{|c|}{ - Mo } & $\%$-berat & 6,99 \\
\hline Luas Permukaan & $\mathrm{m}^{2} / \mathrm{g}$ & 233,62 \\
\hline Volume Pori & $\mathrm{mL} / \mathrm{g}$ & 0,49 \\
\hline Diameter Pori & $\AA$ & 84,18 \\
\hline
\end{tabular}

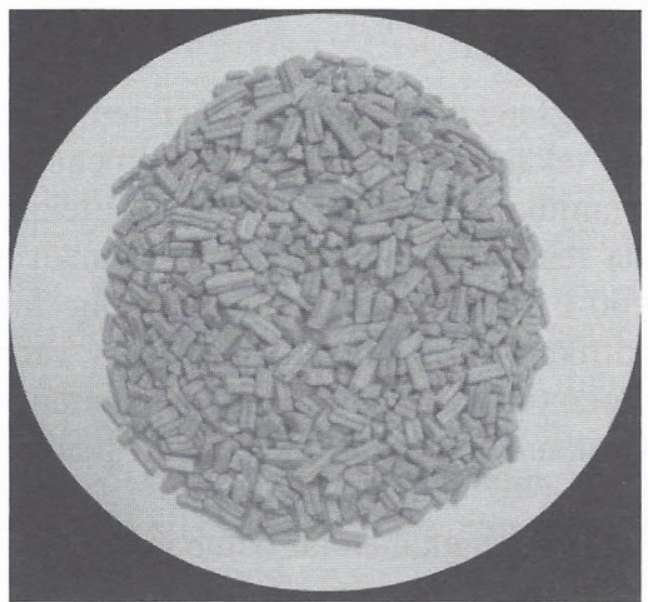

Gambar 3. Katalis Penghidrorengkahan

\section{Peralatan}

Penghidrorengkahan tar batubara menggunakan reaktor autoclave berkapasitas $500 \mathrm{~mL}$ yang dilengkapi sebuah pengaduk dengan sistem horizontal yang kecepatannya dapat diatur dan sistem pemanas reaktor yang dipasang dalam jaket pemanas. Secara keseluruhan reaktor autoclave, pemanasan dan pengaduk terhubung ke panel kontrol digital, dimana kondisi operasi dapat diatur, dikontrol dan dicatat. Gambar reaktor autoclave dapat dilihat pada Gambar 4.

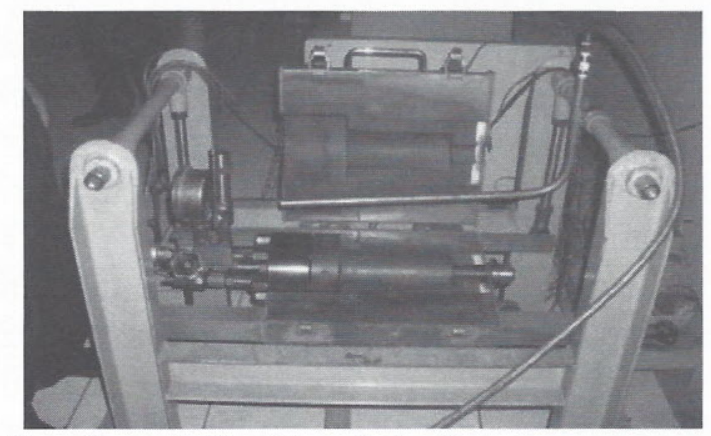

Gambar 4. Reaktor Autoclave

\section{Metoda}

Alur percobaan penghidrorengkahan tar batubara diperlihatkan Gambar 5 . Percobaan di mulai dengan melakukan sampling tar batubara di industri yang menghasilkan tar batubara dari gasifikasi batubara.Karakterisasi sifat fisika dan kimia tar batubara dengan metode berikut : analisaelemen (karbon, hidrogen, nitrogen), ASTM D5291; analisa SG $60 / 60^{\circ} \mathrm{F}$, ASTM D1298; kadar air , ASTM D4006; total sulfur, ASTM D4294; polisiklikaromatik, IP 346.

Penghidrorengkahan tar batubara dilakukan dengan reaktor autoclave dengan katalis nikel molibdenum berpenyangga silika alumina. Katalis ini diaktivasi terlebih dahulu menggunakan proses presulfiding sebelum digunakan dalam penghidrorengkahan. Presulfiding katalis bertujuan untuk meningkatkan aktivitas katalis dengan mengubah sisi aktif dari logam oksida menjadilogam sulfida. Metode untuk presulfiding ada dua macam yakni metode kering dan metode basah. Metode kering, dilakukan dengan menginjeksikan hidrogen sulfida $\left(\mathrm{H}_{2} \mathrm{~S}\right)$ menggunakan aliran hidrogen untuk mengsulfida katalis, sedangkan metode basah dilakukan dengan mencampur katalis dan gas oil yang telah ditambahkan sedikit karbon disulfida $\left(\mathrm{CS}_{2}\right)$ atau dimetil disulfida (DMDS) dan dialirkan gas hidrogen ${ }^{(9)}$.

Penelitian ini menggunakan presulfiding metode basah. Presulfiding dilakukan di dalam reaktor autoclave, dimana katalis (40 gr) disulfidasi dengan DMDS (18,5 mL) dalam solar (200 mL). Tahapan selanjutnya adalah melakukan uji kebocoran terhadap reaktor tersebut menggunakan gas nitrogen, bila sudah dapat diyakinkan tidak terdapat kebocoran pada reaktor maka presulfiding dapat dilakukan. Aliran gas nitrogen digantikan dengan gas hidrogen dan kondisi operasi disetpadatekanan 30 bar dan temperatur $300{ }^{\circ} \mathrm{C}$ selama 200 menit.

Penghidrorengkahan dilakukan dengan sistem batch yaitu umpan tar batubara (50 $\mathrm{mL}$ ) dan katalis (5 gr) dimasukkan ke 


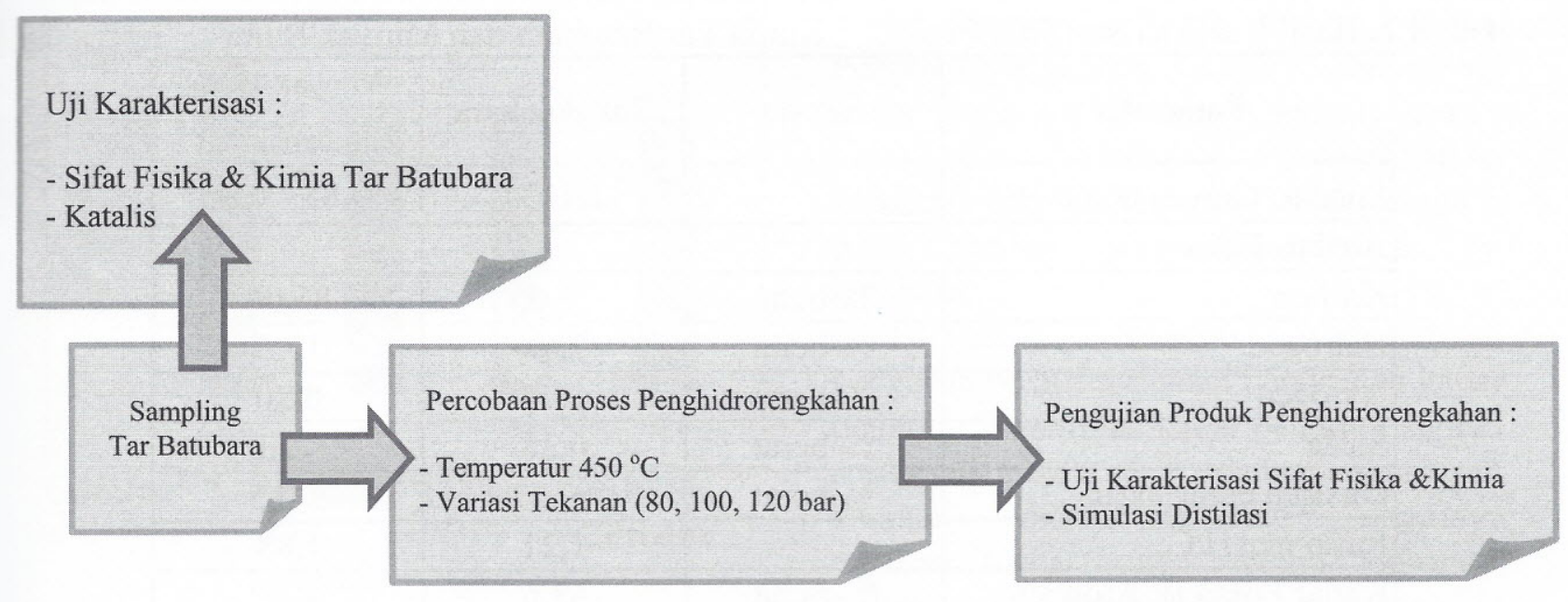

Gambar 5. Alur Percobaan Penghidrorengkahan Tar Batubara

dalam reaktor autoclave. Alirkan gas hidrogen ke dalam reaktor kemudian pemanas reaktor dihidupkan. Penelitian ini dilakukan pada kondisi operasi temperatur tetap $450^{\circ} \mathrm{C}$ dan variasi tekanan $(80,100$ dan 120 bar). Waktu yang dibutuhkan untuk menaikkan temperatur dari temperatur ruang ke temperatur reaksi adalah 30 menit dan penghidrorengkahannya dilakukan selama 1 jam.Uji karakterisasi sifat fisika dan kimia produk penghidrorengkahan menggunakan metode berikut : analisa elemen (karbon, hidrogen, nitrogen), ASTM D5291; analisa SG $60 / 60^{\circ} \mathrm{F}$, ASTM D 1298; total sulfur, ASTM D4294 dan simulasi distilasi, ASTM D2887.

\section{HASIL DAN PEMBAHASAN}

Hasil uji karakterisasi sifat fisika dan kimia tar batubara dapat dilihat pada Tabel 2. Tabel tersebut membandingkan hasil uji karakterisasi tar batubara terhadap karakterisasi minyak bumi konvensional.

Berdasarkan Tabel tersebut terlihat bahwa tar batubara memiliki sifat fisika dan kimia yang hampir mirip dengan minyak bumi, namun tar batubara memiliki kadar specific gravity $60 / 60^{\circ} \mathrm{F}$ 1,1081 dan nilai ini lebih tinggi dari kadar specific gravity $60 / 60^{\circ} \mathrm{F}$ minyak bumi konvensional. Kadar pengotor (impurity) seperti nitrogen dan oksigen yang lebih tinggi jika dibandingkan dengan minyak bumi konvensional. Kadar nitrogen tar batubara $1,74 \%$ berat dan nilai ini lebih tinggi dibandingkan dengan kadar nitrogen dalam minyak bumi konvensional yakni $0,2 \%$ berat. Kadar oksigen tar batubara juga lebih tinggi yaitu $10,87 \%$ berat dibanding kadar oksigen di minyak bumi konvensional yaitu $<0,5 \%$. Kadar sulfur tar batubara $0,38 \%$ berat masih masuk ke dalam kisaran kadar sulfur minyak bumi konvensional yaitu $<2 \%$ berat.

Rasio mol H/C dari tar batubara lebih kecil dibandingkan dengan minyakbumi. Rasiomol H/C ini biasa digunakan untuk memperkirakan kadar aromatik pada umpan. Hasil karakterisasi tar batubara memiliki kadar aromatik yang tinggi terutama kadar poliaromatik sebesar 63,6 \%berat. Nitrogen, sulfur dan oksigen terikat di dalam struktur heterosiklik aromatik tar batubara. Sehingga dibutuhkan proses perengkahan struktur aromatik terlebih dahulu untuk dapat mengurangi kadar tersebut.

Kadar pengotor yang tinggiakan menjadi masalah dalam pemanfaatan tar batubarasebagai bahan bakar minyak, sehingga perlu dilakukan peningkatan mutu tar batubara dengan penghidromurnian yaitu penghidrorengkahan. Proses ini digunakan karena penghidrorengkahan memiliki keuntungan dapat memecah struktur poliaromatik, menghidrogenasi pengotor yang terkandung pada tar batubara dan 
Tabel 2. Hasil KarakterisasiSifat Fisik dan Kimia Tar Batubara dan Minyak Bumi

\begin{tabular}{|l|c|c|c|}
\hline \multicolumn{1}{|c|}{ Parameter } & Satuan & Tar Batubara & $\begin{array}{c}\text { Minyak Bumi } \\
\text { Konvensional }^{10}\end{array}$ \\
\hline Specific Gravity $60 / 60^{\circ} \mathrm{F}$ & - & 1,1081 & $0,85-0,90$ \\
\hline Analisis Elemen & \%-berat & 79,05 & 86,00 \\
\hline Karbon & \%-berat & 7,96 & 13,5 \\
\hline Hidrogen & \%-berat & 1,74 & 0,20 \\
\hline Nitrogen & \%-berat & 0,38 & $<2,0$ \\
\hline Sulfur & \%-berat & 10,87 & $<0,5$ \\
\hline Oksigen perhitungan & - & 1,21 & 1,88 \\
\hline Rasio mol H/C & \%-berat & 63,6 & \\
\hline Kadar Polisiklik Aromatik & \%-berat & 3 & \\
\hline Kadar Air & & & \\
\hline
\end{tabular}

dihasilkan produk cair yang lebih besar. Salah satu parameter operasi yang penting pada penghidrorengkahan adalah tekanan reaktor. Parameter ini dapat meningkatkan proses pemecahan struktur kimia dan pengurangan kadar pengotor.

Penelitian ini menggunakan tekanan hidrogen awal 80 bar (HC1), 100 bar (HC2) dan 120 bar (HC3) pada temperatur tetap $450^{\circ} \mathrm{C}$. Gambar 6 memperlihatkan bentuk fisik umpan tar batubara dan produk penghidrorengkahannya. Visualisasi produk penghidrorengkahan memiliki warna coklat dan jenis cairan yang lebih encer dibandingkan umpan tar batubara. Hal ini memperlihatkan parameter tekanan memiliki pengaruh positif terhadap produk penghidrorengkahan.

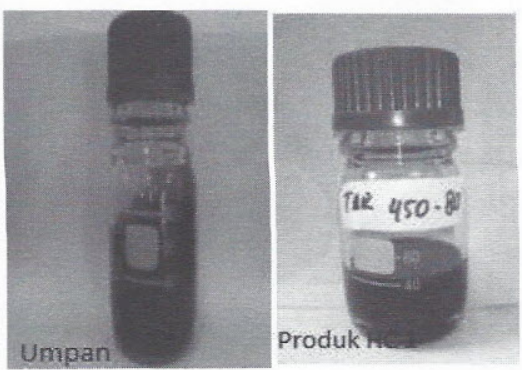

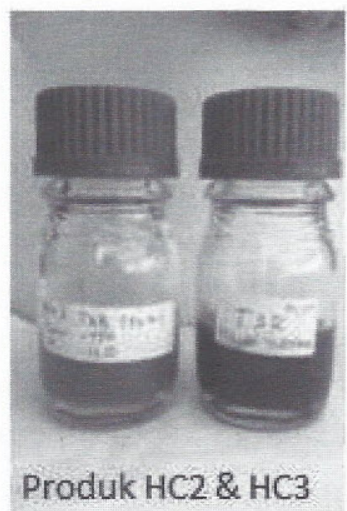

Gambar 6. Umpan Tar Batubara dan Produk Penghidrorengkahan

Gambar 7 memperlihatkan pengaruh tekanan reaktor terhadap SG $60 / 60^{\circ} \mathrm{F}$ produk penghidrorengkahan.Tekanan reaktor memberikan pengaruh positif terhadap parameter tersebut. Kenaikan tekanan reaktor akan meningkatkan proses pemecahan struktur kimia umpan dan meningkatkan konversi umpan sehingga menghasilkan produk penghidrorengkahan dengan struktur yang lebih ringan dibandingkan umpan. Hal ini ini bisa dilihat pada penurunan kadar SG $60 / 60^{\circ} \mathrm{F}$ pada produk penghidrorengkahan. Penurunan SG $60 / 60^{\circ} \mathrm{F}$ terbesar didapat pada HC3 sebesar $19 \%$ dari SG $60 / 60^{\circ} \mathrm{F}$ umpan 1,1081 menjadi 0,9010 . 


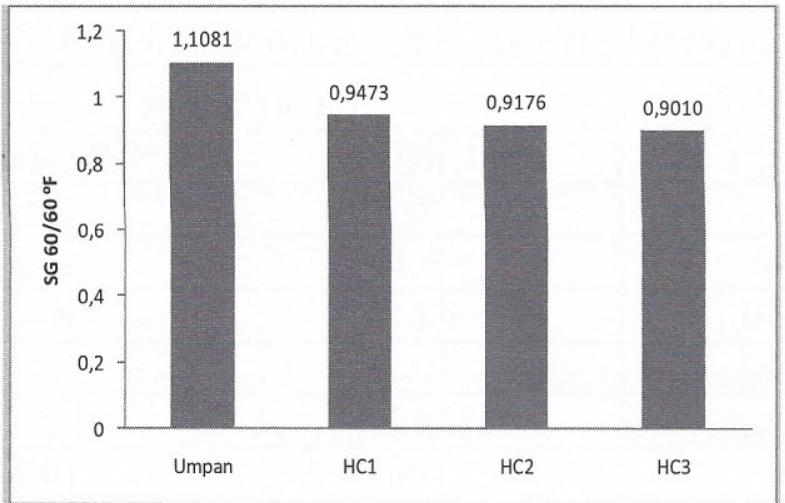

Gambar 7. Pengaruh Tekanan Terhadap SG $60 / 60^{\circ} \mathrm{F} \quad$ Produk

Penghidrorengkahan

Gambar 8 memperlihatkan pengaruh tekanan reaktor terhadap rasio mol $\mathrm{H} / \mathrm{C}$ pada produk penghidrorengkahan tar batubara. Faktor yang berpengaruh pada tekanan reaktor adalah tekanan dan kemurniandari gas hidrogen yang digunakan. Makin besar tekanan gas hidrogen maka tekanan di reaktor akan semakin besar. Tekanan gas hidrogen yang besar berasal dari penggunaan gas hidrogen yang besar dan hal ini menambah jumlahgas hidrogen untuk proses hidrogenasi sehingga kadar hidrogen dalam produk lebih besar dibandingkan umpan tar batubara. Hal ini terlihat dari peningkatan rasio mol $\mathrm{H} / \mathrm{C}$ dari produk penghidrorengkahan. Kenaikan terbesar didapat pada HC 3 sebesar $26 \%$ dari rasio mol H/C umpan 1,21 menjadi 1,53.

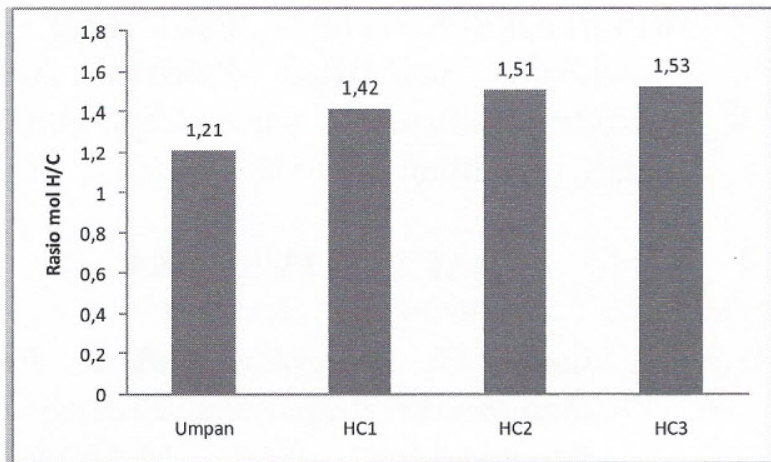

Gambar 8. Pengaruh Tekanan Terhadap Rasio Mol H/C Produk Penghidrorengkahan

Tar batubara mengandung senyawa pengotor seperti sulfur dan nitrogen yang akan berdampak negatif terhadap pemakaiannya sebagai bahan bakar. Penghidrorengkahan dapat mengurangi kadar pengotor tersebut dengan proses hidrogenasi. Gambar 9 memperlihatkan pengaruh tekanan terhadap kadar pengotor pada produk penghidrorengkahan tar batubara.

Parameter tekanan memberikan pengaruh positif terhadap penurunan kadar pengotor.Penurunan kadar pengotor seperti sulfur dan nitrogen dengan kenaikan tekanan disebabkanmakin tingginya tekanan maka kontak antara hidrogen, hidrokarbon (umpan) dan katalis semakin baik. ${ }^{(11)}$ Proses hidrogenasi pada umpan semakin besar dan meningkatkan konversi umpan sehingga dihasilkan produk penghidrorengkahan dengan kadar pengotor yang lebih rendah dibandingkan umpan. Penurunan kadar sulfur terbesar pada $\mathrm{HC} 2$ sebesar $89 \%$ dari kadar sulfur umpan sebesar 0,383 \%berat menjadi 0,043 \%berat. Kenaikan tekanan lebih lanjut tidak menyebabkan penurunan yang signifikan,terlihat pada $\mathrm{HC} 3$ dimana penurunan kadar sulfur hanya 88,5\%.

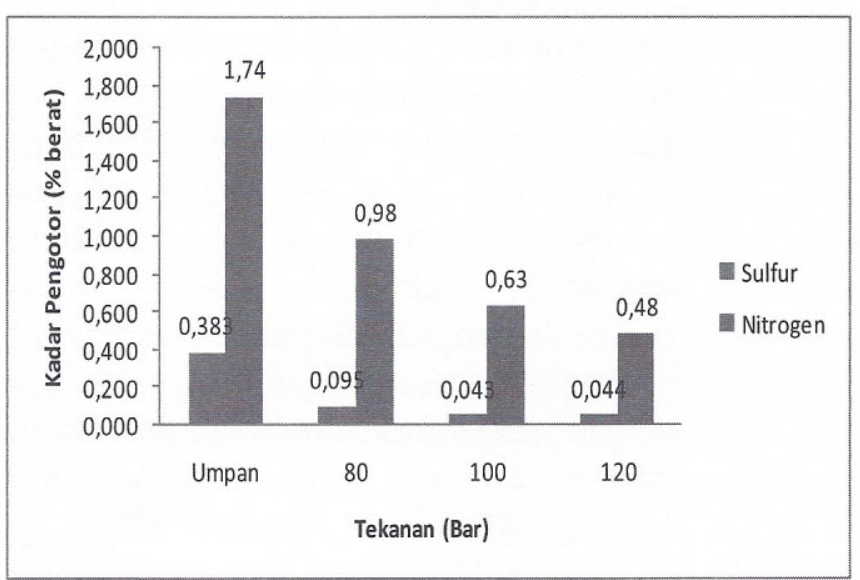

Gambar 9. Pengaruh Tekanan Terhadap Kadar Pengotor Produk Penghidrorengkahan

Kenaikan tekanan lebih lanjut pada pengurangan kadar nitrogen memberikan hasil yang lebih baik. Penurunan kadar nitrogen terbesar didapat pada $\mathrm{HC} 3$ sebesar $72 \%$ dari kadar umpan 1,74 \%berat menjadi 0,48 \%berat.

Produk hasil penghidrorengkahan masih berupa campuran senyawa yang 
Tabel 5. Hasil Simulasi Distilasi Produk penghidrorengkahan Tar Batubara $\left(450^{\circ} \mathrm{C}, 120\right.$ Bar)

\begin{tabular}{|l|c|c|c|}
\hline \multirow{2}{*}{\multicolumn{1}{c|}{ Fraksi }} & \multirow{2}{*}{ Hasil (\% vol) } \\
\cline { 3 - 4 } \multicolumn{1}{|c|}{} & Titik Didih $\left({ }^{\circ} \mathrm{C}\right)$ & Umpan & Produk \\
\hline Fraksi Ringan & $<80$ & 0 & 2.2 \\
\hline Nafta & $80-200$ & 3.1 & 33.8 \\
\hline Distilat Tengah & $200-350$ & 42.3 & 48 \\
\hline Distilat Vakum & $350-520$ & 30.3 & 14 \\
\hline Residu Vakum & $>520$ & 24.2 & 2 \\
\hline Total & & 100 & 100 \\
\hline
\end{tabular}

terdiri dari titik didih dengan rentang yang besar, sehingga perlu dilakukan proses pemisahan dengan distilasi. Distilasi yang dipergunakan dalam penelitian ini menggunakan simulasi distilasi (simdis) dengan kromatografi gas. Dengan mengintegrasikan kenaikan total luas kromatogram dan ini berkaitan dengan titik didih komponen-komponen pada setiap kenaikannya, yang dihitung dari titik didih dari senyawa yang sudah diketahuiyaitu n-parafin sehingga simulasi data titik didih dapat dihasilkan ${ }^{(12)}$. Hasil distilasi ini berupa fraksi-fraksi dalam rentang titih didihnya. Tabel 5 memperlihatkan hasil simulasi distilasi tar batubara dari produk penghidrorengkahan berupa neraca massa pada kondisi operasi temperatur $450^{\circ} \mathrm{C}$ dan tekanan 120 bar.

Simulasi distilasi pada Tabel 5 memperlihatkan fraksi residu vakum dan distilat vakum pada produk penghidrorengkahan jumlahnya berkurang sedangkan fraksi ringan, nafta dan distilat tengah jumlahnya bertambah dimana fraksi ringan $2,2 \% \mathrm{vol}$, nafta $33,8 \% \mathrm{vol}$, distilat tengah $48 \%$ vol. Jumlah nafta yang dihasilkan dari proses ini cukup besar yang awalnya 3,1\%vol menjadi 33,8\%vol. Hasil ini memperlihatkan penghidrorengkahan tar batubara mengkonversi tar batubara menjadi fraksi-fraksi yang lebih ringan dengan jumlah yang lebih baik. Hal ini menunjukan tar batubara berpotensi untuk diolah menjadi bahan bakar minyak dengan penghidrorengkahan.

\section{KESIMPULAN}

Penghidrorengkahan berhasil mengkonversi umpan tar batubara menjadi produk yang lebih ringan. Proses ini dapat menurunkan kadar SG $60 / 60^{\circ} \mathrm{F}$ dan pengotor (sulfur dan nitrogen) serta meningkatkan rasio mol $\mathrm{H} / \mathrm{C}$ pada produk. Proses tersebut juga menghasilkan nafta dalam jumlah cukup besar yang potensial diolah lebih lanjut menjadi bahan bakar minyak. Selain itu, pemanfaatan tar batubara juga dapat menjadi solusi pengolahan limbah.

\section{UCAPAN TERIMA KASIH}

Penulis mengucapkan terimakasih kepada anggota Tim Peningkatan Mutu Tar Batubara "LEMIGAS" dan semua pihak yang telah membantu serta memberikan sumbangan pemikiran sehingga penelitian ini dapat berjalan. Kami juga berterimakasih kepada Pak Huda dari Puslitbang tekMIRA KESDM untuk reaktor autoclave yang dipergunakan dalam penelitian ini.

\section{DAFTAR PUSTAKA}

1. James G. Speight. Synthetic Fuels Handbook: Properties, Process and Performance. The McGraw-Hill Companies, Inc, United State of America, 2008, pp 153-155.

2. Umar Datin Fatia dan Daulay Bukin. Peningkatan Kualitas Batubara Peringkat Rendah dengan Teknologi Upgraded Brown Coal (UBC)". Hasil 
Litbang Pusat Penelitian dan Pengembangan Teknologi Mineral dan Batubara, 2012. http://www.tekmira.esdm.go.id di akses Maret 2014.

3. Chunshan Li and Kenzi Suzuki. Resources, properties and utilization of tar. Resources, Conservation and Recycling 54: 905-915 (2010)

4. Tao Kan, Hongyan Wang, Hongxing $\mathrm{He}$ Chunshan Li, Suojiang Zhang.Experimental study on twostage catalytic hydroprocessing of middle-temperature coal tar to clean liquid fuels. Fuel 90: 3404-3409 (2010)

5. Ying Liu, Werner Hodek, Karl H. van Heek.Characterization of tar, char and gas from pyrolysis of coal asphaltenes. Fuel 77: pp. 1099-1105 (1998)

6. Agus Salim, Bambang Wicaksono T.M, Hari Waskito (Penyunting). Kamus Minyak Dan Gas Bumi Edisi Keenam Cetakan Kedua 2011. PPPTMGB "LEMIGAS", Jakarta, 2009, hal 179

7. Mohan S. Rana, Vicente Sámano, Jorge Ancheyta, J.A.I. Diaz. A Review of Recent Advances on Process Technologies for Upgrading of Heavy Oil dan Residual. Fuel 86: 1216-1231 (2007)

8. James H.Gary and Glenn E. Handwerk. Petroleum Refining Technologyand Economics Fourth Edition. Marcel Dekker. Inc, New York , 2001, pp 139-148

9. Dong $\mathrm{Li}$, Zhen $\mathrm{Li}$, Wenhong $\mathrm{Li}$, Qingchao Liu, Zili Feng, Zheng Fan. Hydrotreating of low temperature coal tar to produce clean liquid fuels.
Journal of Analytical and Applied Pyrolysis 100 : 245-252 (2013)

10. James G. Speight. The Refinery of the Future. Elsevier Inc, UK, 2011, pp 12.

11. J. Ancheyta-Juárez, G. BetancourtRivera, G. Marroquín-Sánchez, A. M. Pérez-Arellano, S. K. Maity, Ma. T. Cortezand R. del Río-Soto. An exploratory study for obtaining synthetic crudes from heavy crude oils via hydrotreating. Energy Fuels 15 : 120-127 (2001)

12. James G. Speight. The Chemistry and Technology of Petroleum, Fourth Edition (Chemical Industries) Fourth Edition. CRC Press, 2006, pp 360-371. 